\title{
O que pode Elegbara? Filosofias do corpo e sabedorias de fresta
}

\author{
What can Elegbara? Philosophies of the body and wisdoms of border
}

\author{
Luiz Rufino*
}

Resumo: Este artigo invoca Exu/Elegbara, esfera de saber negro-africana transladada nos fluxos da diáspora, como princípio explicativo de mundo, potência criativa e disponibilidade conceitual para pensar filosofias montadas e paridas no/pelo corpo. Nesse sentindo, a corporeidade como parte da problemática do conhecimento investe na reflexão e crítica das questões epistemológicas como étnico-raciais. Assim, via giros enunciativos e os conceitos de cruzo, incorporação e mandinga investe-se em um debate que atenta para questões da ordem do racismo epistêmico, colonialidade do ser/saber e a emergência de outras pedagogias no combate as injustiças sociais e cognitivas.

Palavras-Chave: Exu; Corporeidade; Epistemologia; Pedagogia das Encruzilhadas; Descolonização

Abstract: This article invokes Exu/Elegbara, the black-African sphere of knowledge translated into diaspora flows, as an explanatory principle of the world, creative power and conceptual availability to think of philosophies assembled and born in the body. In this sense, corporeity as part of the problematic of knowledge invests in the reflection and critique of epistemological questions as ethnic-racial. Thus, through enunciative turns and the concepts of cross, incorporation and mandinga, one invests in a debate that deals with issues of the order of epistemic racism, coloniality of being / knowledge and the emergence of other pedagogies in combating social and cognitive injustices.

Keywords: Exu; Corporeidade; Epistemology; Pedagogy of the Crossroads; Decolonization

\section{O arrebate do corpo, a ênfase no saber corporal}

Qual é a cor do gorro que veste Exu? ${ }^{1}$ Qualquer uma que ele queira, ele é aquilo que quiser, é um princípio incontrolável. Exu é a divindade mais próxima dos homens, encarnado em nossas existências, desde o grito do recém-nascido ao último suspiro de morte. Já diria o sábio conhecedor do riscado: "Exu é o primeiro na vida e na morte.” Mesmo interpenetrado a todas as faces da existência humana ele ri de nossas limitações, anseios, zomba daqueles que enveredam pelas obsessões de grandeza e certeza. Exu nos faz

\footnotetext{
* Doutor em Educação- (UERJ) e pós-doutorando em Relações Étnico-raciais- (PPRER/CEFET).

E-mail: luizrfn@gmail.com

${ }^{1}$ Esse questionamento se encruza a uma das mais conhecidas narrativas sobre Exu, presente em um dos 256 odus Ifá, em que o orixá veste um gorro de duas cores e serpenteia entre os limites de visão de dois vizinhos que travam uma trágica disputa pela certeza acerca da cor do gorro.

${ }^{2}$ Essa frase foi enunciada pelo sacerdote de candomblé Pai Carlinhos.
} 
sentar no vazio, esculhamba nossas pretensiosas verdades. Constrói ao destruir. No jogo sincopado, o que nos espreita é a queda. Não à toa, é ele o princípio da imprevisibilidade. Assim, o que há de emergir no vazio do sincopado? Exu nos sopra: reinvente-se, crie. Haverá sempre uma possibilidade.

O corpo, princípio de Exu, é esfera mantenedora de potências múltiplas, o poder que o incorpora o transforma em um campo de possibilidades. O corpo em performance nos ritos se mostra como arquivo de memórias ancestrais, um dispositivo de saberes múltiplos que enunciam outras muitas experiências. Assim, o saber corporal ${ }^{3}$, inteligibilidade e motricidade emanada dos suportes físicos revelam o elemento e núcleo responsável pelas manifestações e reproduções das sabedorias negro-africanas transladadas e ressignificadas na diáspora.

O saber corporal ${ }^{4}$ constitui-se como o núcleo de uma série de ações inscritas enquanto estratégias, cuja finalidade é a edificação de espaços onde as identidades sejam vigoradas. Assim, nas práticas cotidianas, as ações advindas dessa sabedoria operam na tessitura de identidades reivindicadas a partir de seu próprio núcleo. Esse processo enuncia identidades corpóreo-gestuais. Nessas vias, as dimensões dos ritmos corporais e a movimentação gestual apontam as encruzilhadas em que as culturas negras estão lançadas. Encruzas essas que alinhavam os permanentes conflitos, embates, adaptações e negociações em que esses saberes estão lançados.

$\mathrm{O}$ arrebate do corpo a partir de Exu, bem como a emergência e a credibilização dos seus saberes implicam no exercício de rolês epistêmicos ${ }^{5}$ movimentos que nos deslocam ao encontro de caminhos pluriepistêmicos e polirracionais. Esses cursos, cruzados e imantados pelo axé de Exu, se atam de forma ética/estética às orientações antirracistas/decoloniais, e se entrecruzam compartilhando o ideal de uma transformação radical implicado na luta pela equidade.

A instituição colonial edificou-se a partir da pilhagem de corpos indígenas, negros e femininos brutalmente assassinados, desencantados, desmantelados e blindados cognitivamente ${ }^{6}$. O corpo, como um suporte que monta outras sabedorias, um inventário e mola propulsora de ações táticas firma como um assentamento de outros modos de racionalidades, opostos aos praticados pelo Ocidente. Dessa forma, o corpo se consagra como a própria instituição que compreende a existência do ser em integralidade com a comunidade e o universo ${ }^{7}$.

\footnotetext{
3 TAVARES, Dança de guerra- arquivo e arma: elementos para uma Teoria da Capoeiragem e da Comunicação Corporal Afro-Brasileira, 2015.

${ }^{4}$ Ibidem, p. 25-26.

${ }^{5}$ RUFINO, Exu e a Pedagogia das Encruzilhadas, p. 41.

6 TAVARES, Colonialidade do Poder, Cooperação Internacional e Racismo Cognitivo: Desafios ao Desenvolvimento Internacional Compartilhado, 2015.

${ }^{7}$ Ibidem.
} 
Assim, saio em defesa de que Exu é o elemento que nos possibilita um reposicionamento do corpo no debate epistemológico. A disponibilidade conceitual inscrita nesse signo nos revela dimensões historicamente negadas pelos regimes de verdade mantidos pelo ocidente. A emergência de novas perspectivas, a partir de Exu, nos permite credibilizar princípios, domínios e potências do ser que transgridam os parâmetros da política colonial. Cabe ressaltar que essa política de dominação exercida há mais de quinhentos anos é demasiadamente concentrada na violência contra os corpos. Assim, a violência praticada nos cotidianos da colônia autoriza a coisificação dos seres, do mesmo modo que a coisificação perpetua a violência. Nesse sentido, funda-se uma lógica de governabilidade da vida, uma maldição que substancia o sentido existencial do homem branco (colonizador) em detrimento do desvio existencial do ser não branco (colonizado).

Assim, a política colonial foi e permanece sendo uma biopolítica. Por aqui, há mais de cinco séculos se empilham corpos, se cavam covas rasas, assim como se investe em tecnologias de contenção, tortura e docilização dos mesmos. Para além da manutenção do genocídio das populações não brancas (negros e indígenas), há também o investimento na perpetuação do esquecimento. A empresa colonial mata de inúmeras formas, seja com balas, com a precarização da vida, com o desarranjo das memórias, com o desmantelo cognitivo, com a coisificação do ser e a produção e a manutenção do trauma.

Nesse sentido, cabe ressaltar a estratégia política da ordem colonial em interditar, demonizar e perseguir o signo Exu, já que o mesmo emerge como esfera ôntica, epistêmica e semiótica que azucrina os limites da arrogância e intransigência impostos pela razão moderna-ocidental. Em outras palavras, e em diálogo com as reflexões de Grosfoguel, nos cabe problematizar as dimensões do terror colonial lendo o caráter tático do racismo epistêmico e a sua economia redutora da experiência social no que tange o ataque e extermínio de signos e gramática em favor de uma racionalidade que opera como o próprio olho de Deus ${ }^{8}$.

Exu é a força motriz do universo, um poder incontrolável e impossível de ser dominado. A interação com o mesmo reivindica uma ética responsiva, uma vez que é ele o múltiplo no uno e o um multiplicado ao infinito, está em tudo e em tudo está. Assim, Exu, como uma potência inesgotável, dobra qualquer perspectiva de escassez. Por isso ele é o senhor dos caminhos (Onã), pois o seu caráter dinâmico é uma constante produtiva. São inúmeros os mitos em que Exu protagoniza pelejas vencendo a morte, e, em grande parte delas, Exu age através de sua perspicácia, a ludibriando, pregando peças nela e a afastando de afetar aqueles a quem ela se destina. Como no caso do mito em que Exu salva Orunmilá

\footnotetext{
${ }^{8}$ GROSFOGUEL, A estrutura do conhecimento nas universidades ocidentalizadas: racismo/sexismo epistêmico e os
} quatro genocídios/epistemicídios do longo século XVI, p. 28. 
da morte, servindo a ela a comida que Orunmilá ofertou como ebó. Assim, a morte não poderia mais matá-lo, pois havia se alimentado da sua comida. ${ }^{9}$

É importante ressaltar que, em grande parte das narrativas míticas, a noção de morte transcende a dimensão de uma simples oposição à vida. Nesse sentido, destacam-se as perspectivas explicativas assentes na cosmogonia iorubana e, respectivamente, nos cruzos $^{10}$ da afro-diáspora, em que a noção de morte, para além da constituição da matéria, se vincula às noções de esquecimento, escassez, desencante e perda de energia vital. Esse giro explicativo é fundamental para credibilizarmos os cultos à ancestralidade - suas invocações e encarnações - como um elemento emergente e fundamental na reinvenção da vida na diáspora, na medida em que abrem um campo de possibilidades de combate à escassez.

Assim, a dimensão do corpo, para essas sabedorias, transcende os limites do emprego usado pela lógica ocidental. O mesmo é suporte de sabedorias múltiplas que baixam e o encarnam; é também um elemento de imantação e diálogo constante (cruzo) com o campo multidimensional. O corpo potencializado pelo transe (deslocamento e trânsito por múltiplas dimensões) passa a não ser meramente passivo às violências a ele empregadas, se desgarra da fixidez material imposta pelo substantivo racial e passa a operar inventando/inventariando ações de transgressão e montagem.

Nesse sentido, reposicionar o corpo a partir de um curso de ser/saber outro, perspectivado pelas encruzilhadas de Exu, perpassa por credibilizá-lo como potência. Assim, emerge como caminho não somente aquilo que, em primeiro momento, é o corpo nos limites de sua materialidade, mas aquilo que o filósofo afro-brasileiro Vicente Ferreira Pastinha atou como sendo "tudo que o corpo dá”. Ou seja, a integralidade entre suporte físico e suas potências, que eu compreendo como as operações de Bara e Elegbara, o corpo físico e sua espiritualidade (potências).

Dessa forma, é a partir desses conceitos que adentramos as práticas de saber (performatividades) da afro-diáspora como repertórios táticos antirracistas/decoloniais inventariados nas dimensões da corporeidade. Mandinga, incorporação, ginga, negaça, transe, rolê, efó, amarração, feitiço, terreiro, esquiva, drible, entre outros inúmeros conceitos praticados como sabedorias de fresta, são marcas que tecem esse inventário assente nos limites do corpo.

Exu é aquele que tem a cabeça afiada como a ponta de um obé11. Ifá nos conta que sobre a cabeça desse orixá não repousam fardos, ele é um único corpo, um ser integral, que sente/age e reverbera as potências criativas do ser supremo em seu todo. Exu, quando se parte, é porque de seus pedaços emergirá um novo ser, tão completo e integral como

\footnotetext{
${ }^{9}$ Essa passagem está contida em um dos 256 odus Ifá. Nela também se ressalta a dimensão de uma ética responsiva entre Exu, Orunmilá e Iku.

${ }^{10}$ RUFINO, Exu e a Pedagogia das Encruzilhadas, p.103.

${ }^{11}$ Faca.
} 
aquele que havia antes. Ele é o movimento primordial, de tempos remotos, antes mesmo da criação do universo, o dinamismo dessa força gerou a primeira matéria, um ponto concentrado que se materializou imantando toda a força propulsora. Esse ponto concentrado, materialização da potência de Exu, não suportou conter toda a força criativa e explodiu. Da própria energia da explosão gerou-se o movimento de ordenação do universo. Dos pedaços estilhaçados por todo o infinito nasceram novas criações, a reverberação desse evento gerou a possibilidade do acontecer, do devir. É por isso que Exu é lido como a espiral do tempo, o primeiro corpo, aquele que é dotado de inteligibilidade, que atravessa tudo e todos, pois é o próprio acontecimento em si.

Por um projeto político/poético/ético intitulado Pedagogia das Encruzilhadas ${ }^{12}$ o corpo e os seus saberes emergem a partir do referencial Exu. O corpo, primeiro lugar do ser no mundo, suporte em que baixam potências múltiplas. Esse elemento, alvo de tortura, objetificação, cárcere e estupro durante a pavimentação do Novo Mundo, é aqui lido a partir dos domínios e potências de Bara (dono do corpo) e Elegbara (senhor do poder mágico). Minha intenção ao invocar esses domínios é praticar uma verdadeira arruaça teórico-metodológica, porém, comprometido com o espírito exusíaco ${ }^{13}$ de reorganizar a partir da desordem, para apontar novos caminhos. Isso se faz necessário na medida em que o colonialismo concentrou seus ataques primeiramente nas dimensões do corpo.

Essa trilha aberta por Fanon ${ }^{14}$ é incursionada por Tavares ${ }^{15}$, que nos lembra que os processos ditos civilizatórios, praticados via escravidão/colonialismo, transformaram o ser negro em algo coisificado. De um corpo integrado às múltiplas dimensões de suas cosmovisões, instância do sagrado, como também de toda e qualquer possibilidade criativa, o corpo negro foi transformado em peça ${ }^{16}$ de um processo de transformação material. Exatamente o que Mbembe ${ }^{17}$ chamou de "homem metal" ou "homem niquelado", aquele que só é tido como possível a partir de seu caráter mercantil, de seu desvio ontológico, para ser fundido como uma nova forma nas forjas do Novo Mundo.

Como parte integrante da agenda curricular do Estado Colonial, os modos de educação praticados via escolarização, ao longo dos tempos, reificaram os ideais dominantes. Assim, manteve-se de forma institucional a lógica de disciplinarização dos corpos, os desmantelos, blindagens e desordens das memórias e das cognições. Plantou-se na subjetividade dos seres da colônia a toada "preto não tem história”, "o preto é mais adaptado ao trabalho braçal”, "preto é desalmado". A tríade colonialismo, igreja e ciência

\footnotetext{
${ }^{12}$ RUFINO, Exu e a Pedagogia das Encruzilhadas, 2017.

${ }^{13}$ SIMAS; RUFINO, Fogo no Mato- A Ciência Encantada das Macumbas, p. 113.

${ }^{14}$ FANON, Os Condenados da Terra, 1968.

15 TAVARES, Dança de guerra- arquivo e arma: elementos para uma Teoria da Capoeiragem e da Comunicação Corporal Afro-Brasileira, 2015.

${ }^{16}$ Segundo Tavares, a denominação era justamente a de peça. O corpo negro, dado que sua condição de humanidade desaparecia, era uma ferramenta descartável.

${ }^{17}$ MBEMBE, Crítica da razão negra, 2014.
} 
operou no desmembramento da integralidade entre mente, corpo e espírito e na transformação dessas três instâncias como partes a serem cultivadas de forma separada. A invenção do ser via essa lógica dominante perpassa, então, pela vigilância do corpo (pecado), a edificação da mente (racionalidade) e a salvação do espírito (cristianização).

Para o ser negro, fixado a uma condição vacilante, animalizado, coisificado e fundido, nas fornalhas coloniais, nos moldes do lucro, o que resta é a contenção dos seus impulsos primitivos por meio da subordinação do corpo (cativo, objeto sexual, brinquedo, alegoria), da infantilização da mente (não fala, ingênuo, imaturo, não inteligível e não sofisticado) e da conversão da alma (colonização cosmológica, monologização da linguagem e submissão aos regimes de punição).

Porém, o mesmo corpo que é investido de violência para a sustentação desse regime é também o corpo que vibra as potências da imprevisibilidade e das possibilidades. É o corpo que nega, dissimula, faz a finta, enfeitiça, joga, finge que vai, mas não vai. É a sabedoria de fresta da síncope, a invocação da palavra que constrói mundos, a encarnação do ser em outras esferas, a ginga que vadeia ocupando os espaços vazios e fazendo do pouco muito. É o corpo de Bara e Elegbara, o corpo de transgressão e resiliência. Aquele que faz do seu suporte físico arquivo, arma, amuleto, totem e terreiro. Aquele em que a mente vagueia no cruzo entre sentir/fazer/pensar, se permitindo montar por experiências cosmopolitas, pulsada por saberes fronteiriços.

\section{Incorporação e mandinga: o bailado das sabedorias de fresta}

As produções discursivas assentes nos princípios de Bara e Elegbara esculhambam a linearidade histórica e a suposta supremacia dos conhecimentos versados pelo Ocidenteeuropeu. As potências de Exu nos movem para outras rotas. Trabalho com uma espécie de síntese desses infinitos discursos pulsados pelos saberes corporais a partir da máxima pastiniana que diz: "tudo que a boca come e tudo que o corpo dá!” Assim, nessa máxima, compreendo todos os saberes e possibilidades de enunciação advindas do corpo, sejam verbais ou não. Até mesmo aquelas difíceis de serem classificadas em uma dessas categorias, como as negaças, as mandingas e as demais mentiras ${ }^{18}$ envoltas aos encantamentos da magia. A questão que me mobiliza é o deslocamento para um pensamento de fronteira ou ciência encantada/epistemologia da macumba ${ }^{19}$, referenciada por Exu, onde o corpo aparece como elemento fundante e integral no que tange à produção e a perpetuação do saber.

Desde os mitos iorubanos até as ressignificações de Exu nas travessias pelo Atlântico, o corpo cumpre função elementar como via existente, explicativa e possível. Não

\footnotetext{
${ }^{18}$ Mentira é um termo recorrente na capoeira para se referir aos poderes e efeitos das mandingas.

${ }^{19}$ SIMAS; RUFINO, Fogo no Mato - A Ciência Encantada das Macumbas, p.11.
} 
só uma visão de mundo, mas o próprio conceito de mundo perpassa pelas potências e pela fisicalidade do corpo. Assim, a concepção de que o corpo (individual) é apenas parte de um mundo é rasurada para a inscrição de uma lógica que rompe com o binarismo 'todo e parte'. O corpo é o registro do ser no mundo, como do mundo no ser. O que nos permite nos lançar sob essa perspectiva são as múltiplas faces de Exu e seus princípios explicativos.

Assim, de Yangí, a pedra de laterita, a protomatéria da existência, ao pião de Òkòtò, aquele que gira como espiral das existências sem que não se alcance seu cume. De Enugbarijó, aquele que carrega um pedaço da boca de todos os seres, o princípio da restituição, das transformações radicais, até os efeitos mágicos do poder de Elegbara. De Bara, o suporte físico, a materialidade, até a humanidade demasiada, a contradição e ambivalência do povo de rua ${ }^{20}$. Dos caminhos e caminhantes de Onã até o riso e a alegria transgressora de Odara. Em todas as carapuças vestidas sobre o mesmo ser está a se imantar um múltiplo e inacabado inventário de conhecimentos que revelam o corpo, o que ele pode e dá como elemento construtor de uma contranarrativa à modernidade, combatente da miséria e da escassez.

O corpo, pulsado por Exu, radicaliza com a problemática do conhecimento historicamente tutelado pelo regime monológico do mundo ocidental. Exu confronta com a problemática epistemológica na medida em que lança a noção de que todo conhecimento só se manifesta na medida em que é incorporado. A incorporação ${ }^{21}$ historicamente marcada pelas produções de temor, impossibilidade, desvio e subalternização advindas do colonialismo e de sua teologia política cristã, é aqui reinscrita. $\mathrm{Na}$ Pedagogia das Encruzilhadas desatam-se os sentidos postos pelas marafundas coloniais para reinscrever a incorporação como uma noção que engloba os inúmeros saberes praticados, vibrados nos tons do pensarsentirfazer ${ }^{22}$ A noção de incorporação aqui defendida, além de praticar um rolê epistemológico, fuga para outras zonas de fronteira, também pratica o ebó epistemológico ${ }^{23}$ procedimento que lança as questões do saber nas vias do encantamento e da retomada da espiritualidade.

A espiritualidade retorna ao cerne das questões do conhecimento na medida em que não há desvinculação das instâncias corpo, mente e espírito. Os conhecimentos, praticados a partir de outra concepção de ser, esse imbricado às tessituras e interações da vida nesses outros modos, revela uma dimensão do humano que se fundamenta em sua integralidade. Dessa forma, há uma série de deslocamentos a serem feitos: o primeiro seria o da noção de razão vinculada estritamente à atividade da mente e do pensamento; num segundo momento, a da noção de corpo rigorosamente vinculada às ordens dos impulsos, instintos,

\footnotetext{
${ }^{20}$ RUFINO, Exu e a Pedagogia das Encruzilhadas, p.161.

${ }^{21}$ Ibidem, p. 198.

22 CARVALHO; FLOREZ, Encuentro de Saberes: proyecto para decolonizar el conocimeto universitário eurocênctrico, 2014.

${ }^{23}$ RUFINO, Exu e a Pedagogia das Encruzilhadas, p. 194.
} 
animalidades, e à presença e consequente necessidade de vigilância do pecado; e, em terceiro, a da noção de espiritualidade ligada às instâncias do sublime, da santidade, da evolução e do distanciamento e desprendimento dos referenciais corpóreos. Essas três perspectivas apontadas são rasuradas para serem reinscritas sob outro arranjo, referenciado por outras lógicas. Esses outros modos são impossíveis de serem lidos sem que sejam compreendidos na integralidade e interação de suas instâncias.

Dessa forma, a espiritualidade não se opõe ao saber, que, por sua vez, está diretamente imbricado à condição da experiência dos sujeitos no mundo (corpo) e de suas práticas (incorporações). A ideia de um corpo físico alocado em um polo oposto ao das imaterialidades do espírito não se sustenta nas lógicas assentes nos saberes aqui elencados. Talvez esse seja um dos caminhos para problematizarmos os genocídios produzidos contra as populações negras e indígenas no Brasil. A morte do corpo físico acompanha a lógica de expurgar os saberes e as subjetividades produzidas e incorporadas pelos sujeitos que vibram em outro tom e se referenciam por outros modos de racionalidade.

Assim, existe uma lógica por trás de séculos de assassinatos. O que talvez alguns apontem como uma fragilidade presente no meu argumento, na medida em que a minha fala pode tender a determinadas generalizações, eu defendo que é a lógica perpetuada ao longo do tempo, nada mais do que a ortopedia do colonialismo/colonialidade. Não à toa, Fanon amarrou o ponto atando os diferentes aspectos entre as dimensões físicas e simbólicas.

Retorno ao pensamento de Fanon destacando mais uma vez o aspecto concernente à linguagem ${ }^{24}$, no que ele chamou de colonialismo epistemológico, e as operações do racismo nos cotidianos das mulheres e homens negros. Sobre outro aspecto, disparou denunciando a violência em estado bruto que fundamenta o sistema colonial, revelando suas múltiplas faces experienciadas sob diferentes dimensões do corpo e da existência do ser.

Fanon é novamente invocado para baixar nesta encruza textual e nos ajudar a enfrentar algumas demandas. Se outrora foi ao campo de batalha, aqui, no agora, é invocado para adentrar esse campo de mandinga. O chamo para destravar os nós do corpo, uma vez que venho a defender a noção de mandinga ${ }^{25}$ com a sapiência do corpo. $\mathrm{O}$ racismo e o colonialismo se engendram nas dimensões mais profundas das existências, por isso, para uma transformação radical, teremos de apostar em possiblidades não credibilizadas pelo Ocidente. É isso que busca a Pedagogia das Encruzilhadas, a aposta se dá nos poderes que operam nas frestas e nos cruzos. Assim, aposta-se nas sabedorias operadas em viés, nas gingas, rolês, pontos atados, ebós, encantamentos e incorporações.

\footnotetext{
${ }^{24}$ FANON, Pele Negras, Máscaras Brancas, 1968.

${ }^{25}$ RUFINO, Exu e a Pedagogia das Encruzilhadas, p. 87.
} 
O preto velho, egun da afro-diáspora, me sopra no ouvido: é no território corporal que serão investidas as ações do racismo/colonialismo, é nos limites do corpo que serão praticados os primeiros golpes - “olhe, um preto!" ${ }^{26}$. Seguindo as trilhas de Fanon, compreenderemos que, abaixo do esquema corporal, há um esquema histórico racial subjetivamente plantado e tecido não pelo que o suporta, mas pelo outro, o branco. "Eu existia em triplo: ocupava determinado lugar. Ia ao encontro do outro... e o outro, evanescente, hostil, mas não opaco, transparente, ausente, desaparecia. A náusea...” ${ }^{27}$.

Os desmantelamentos cognitivos, os desarranjos da memória, o ataque à consciência coletiva, o racismo, substância elementar do colonialismo, apresenta formas sofisticadas de operação. O racismo epistemológico é parte integrante da política de morte alçada pela empresa colonial. Nesse sentido, pratiquemos as frestas, invoquemos a espiritualidade vadia que nos arrebata no jogo de corpo para praticarmos o que chamo de rolê epistemológico e saltarmos nos vazios deixados. Fanon nos ajuda, uma vez que ressalta a emergência de um giro enunciativo, desdobra as questões da linguagem, a elegendo como território a ser pensado. Percebamos que a virada linguística praticada por Fanon pode ser também lida nos termos exusíacos, como “tudo aquilo que o corpo dá"! A magnitude da contribuição de Fanon é justamente o que se cruza com uma perspectiva elegbariana.

O colonialismo funda um mundo partido, maniqueísta, porque as condições para ser aceito nos ditames coloniais implicam submeter o corpo a uma série de disciplinas; o corpo do colonizado está em constante estado de tensão. As musculaturas, os arranjos corpóreos, as palavras, a rítmica e as entonações. O corpo em constante estado de tensão se arranja para ser aceito, para se forjar como algo novo, porém nunca aceito, carregando o fardo do desvio. Fanon ${ }^{28}$ leu o mundo colonial como um mundo cindido, polarizado, imóvel. Mundo que edifica os monumentos de civilidade como cavalos de Troia. O que era o presente dos gregos senão uma marafunda das brabas? Um artefato encarnado pelo espírito da barbárie ${ }^{29}$.

No mundo colonial, mesmo sendo lançado à força ao enquadramento, mesmo sendo vítima de um desmantelo cognitivo e de uma desordem das memórias, o corpo ainda é capaz de encontrar rotas de fuga. As encruzilhadas me apontam que, mesmo que o indígena ${ }^{30}$ aprenda primeiramente a se pôr no seu lugar, aprende também a burlar essa regra. Fanon foi certeiro ao expor os sonhos do colonizado como sonhos musculares, sonhos de ação e de agressividade. Segundo ele, "Eu sonho que dou um salto, que corro,

\footnotetext{
${ }^{26}$ FANON, Pele Negras, Máscaras Brancas, 2008.

${ }^{27}$ Ibidem, p. 105.

${ }^{28}$ FANON, Os Condenados da Terra.

${ }^{29}$ Menção ao pensamento de Walter Benjamin.

30 O termo 'indígena' aqui é utilizado como expressão que alude ao caráter etnocentrado. Sobre essa discussão, ver MASOLO, Filosofia e conhecimento indígena uma perspectiva africana.
} 
que subo. Sonho que estouro na gargalhada, que transponho o rio com uma pernada, que sou perseguido por bando de veículos que não me pegam nunca” ${ }^{31}$.

Porém, a ambivalência do mundo colonial forja também sujeitos abusados, desobedientes, que fazem suas traquinagens nos vazios deixados ou simplesmente jogam o jogo incorporando outros sentidos. Por mais que Fanon me diga que "o colonizado não cessa de se libertar entre nove horas da noite e seis da manhã” ${ }^{22}$, eu não o desminto, mas encruzo algo à sua fala, já que nas bandas de cá "malandro dorme com um olho aberto e outro fechado" 33 !

Ah, as batalhas de corpo, os jogos de valentia, as vadiações do jogo da capoeira nos guardam muitas histórias. Se lança a pergunta "Mestre, o que é Valentão?" ${ }^{34}$. O mestre responde: "Valentão é um cara pior do que a gente." "Ora, como assim mestre?" O mestre solta o verbo: "Sim! Porque ele é mais educado, mais gentil! Valentão não gosta de injustiça. Valentão vê a polícia maltratando um, vai lá e bate na polícia, não deixa que as coisas ruins cheguem na comunidade dele. Eu vou te apresentar dois Valentões!”

As formas de invenção da vida nas bandas de cá do Atlântico são saberes de frestas presentes em múltiplas práticas que têm por efeito despachar o carrego do racismo e colonialismo. No que tange às dimensões do corpo, busca-se o seu encante como suporte de memórias e saberes a partir da perspectiva lançada pela noção de incorporação ${ }^{35}$. A incorporação, noção que credibiliza os saberes praticados, os saberes em performance, parte do pressuposto de que todo saber, para se manifestar, necessita de um suporte físico. O suporte físico é, por sua vez, parte do saber, não há separação. O suporte físico - corpo humano ou outra materialidade - é incorporado por um efeito, um poder que o "monta".

Bara e Elegbara são noções que compreendem domínios e potências que se interligam e fundamentam outras bases explicativas necessárias para um giro epistemológico. Os domínios e potências de Bara e Elegbara são lidos no cruzo com as palavras de Mestre Pastinha. Ao ser questionado sobre o que seria a capoeira, o mestre respondeu: “capoeira é tudo que a boca come e tudo que o corpo dá!” A máxima cunhada pelo mestre é seminal, é como se dissesse tudo e ainda assim abrisse caminho para ainda muito se falar. Em outros termos, firmo o ponto, as palavras de Mestre Pastinha, assim como a capoeira, são exusíacas. Ora, não é Exu o dono do corpo, o senhor das potências do corpo e também aquele que bota palavras em nossas bocas?!

A relação de Exu com o pensamento de Mestre Pastinha ainda nos apresenta outra interface. O domínio de Exu intitulado como Enugbarijó, o Senhor da boca coletiva, nos diz sobre aspectos que podem ser percebidos na capoeira, mas também em todas as dinâmicas

\footnotetext{
${ }^{31}$ FANON, Os Condenados da Terra, p. 39

32 Ibidem.

${ }^{33}$ Aforismo versado nas umbandas e macumbas cariocas pelas entidades de malandros.

${ }^{34} \mathrm{O}$ referido mestre é Gerson Quadrado. Essa história me foi passada por mestre Plínio.

${ }^{35}$ RUFINO, Exu e a Pedagogia das Encruzilhadas, 2017.
} 
de transformação, reprodução, multiplicação, possibilidade, imprevisibilidade, criação, comunicação, mediação e tradução. A noção de Enugbarijó é também conhecida popularmente como a boca que tudo come. Assim, seu Pastinha, ao lançar uma amarração contendo seu pensamento acerca da capoeira, definiu os saberes circundantes ao jogo de corpo cruzando-o aos domínios de Enugbarijó, Bara e Elegbara. Diria que o mais fascinante da máxima cunhada pelo mestre é o seu caráter inacabado, aberto ao imprevisível e a toda e qualquer possibilidade de se apresentar em um outro tom.

A noção de Enugbarijó integra a Pedagogia das Encruzilhadas encruzando todas as travessuras teóricas/metodológicas propostas. Os domínios e potências de Exu, enquanto boca que tudo come, são abarcados pela pedagogia montada por Exu como um conceito fundamental, na medida em que a mesma versa sobre transformações radicais. Em uma perspectiva de mundo em encruzilhadas existe a necessidade de, nos cruzos praticados, engolirmos algumas coisas e cuspirmos de forma transformada. Enugbarijó versa sobre a capacidade de restituirmos algo de forma transformada, se come de um jeito para se cuspir de outro.

As noções de incorporação e mandinga estão necessariamente encruzadas pelos domínios e potências de Bara, Elegbara e Enugbarijó. A partir do referencial Exu, escrever uma tese, recitar uma poesia, ler um tratado, falar múltiplas línguas são saberes incorporados tanto quanto o tocar tambor, o sambar no miudinho, a esquiva e o "entrar sem ser percebido e sair sem ser lembrado". Todas essas formas são saberes assentes nos domínios e potências de Exu. A mandinga, versada aqui como uma das formas de sapiência do corpo, vincula-se às dimensões da incorporação, porém ressalta aspectos ímpares no que tange às suas produções e manifestações.

As mandingas estariam vinculadas aos saberes corporais envoltos a atmosferas mágicas, únicas e intransferíveis. A mandinga lida como a sapiência do corpo é aquele tipo de saber que não pode ser traduzido por outra textualidade que não sejam as pertinentes aos limites do próprio corpo. O que proponho, nesta obra, não é a noção de mandinga como concebida e praticada pelos mestres mandingueiros ${ }^{36}$, mas sim um cruzo, uma amarração conceitual.

A mandinga na Pedagogia das Encruzas se consiste como a sapiência do corpo envolta à atmosfera da magia e aos procedimentos do encantamento. Essa só é possível vislumbrada no rito, na performatividade em consonância com os elementos que compõem a dimensão da magia.

Destrói-se para se construir novamente. Para aqueles que foram relegados ao esquecimento, ao desvio e à não existência, o que cabe é a invenção. A transformação do mundo perpassa pela invenção de novos seres, essa é a pedra cantada pelo preto velho

\footnotetext{
${ }^{36}$ Mestres mandingueiros são como são reconhecidos os mestres da capoeiragem que compreendem as habilidades do que se entende por mandinga.
} 
Césarie $^{37}$ e praticada pelos corpos de saber na diáspora, aqueles que gingam, buscam no vazio o golpe não necessariamente desejável, mas possível. É necessário soltar a mandinga, mergulhar nesse campo de potências ainda pouco conhecido por nós, seres assombrados que desconhecemos os próprios encantos do corpo. Mestre Canjiquinha, capoeira, mandingueiro, filósofo da ancestralidade já enunciaria em uma de suas máximas: "as ideias estão no chão, eu tropeço encontro soluções."

A mandinga é veneno e remédio, é brinquedo e faca de ponta. Foi através da mandinga, sapiência do corpo envolta ao encante, que se transformou a vadiagem em vadiação. Assim, virou-se de ponta cabeça, reinscreveram-se lógicas, apontou-se para novos caminhos. A vadiagem, dos modos de fazer perseguidos e reprimidos conforme a lei aprovada no código penal de $1890^{38}$, foi ressignificada como vadiação. Rasura-se a invenção do crime para atar modos de potencialização da vida. A vadiação compreende as experiências lúdicas e afirmativas praticadas nas ruas, rodas e terreiros, fundamentadas nos ritos dos praticantes de frestas.

Ginga o capoeira, o malandro, o vadio... o chapéu de lado, o tamanco arrastando, a navalha no bolso e o lenço no pescoço ${ }^{39}$. O capoeira, o mandingueiro, o corpo arrebatado pelas potências de Elegbara, eis o inventor da vadiação, aquele que seu Canjiquinha definiu como

Almas vibrantes em corpos orgulhosos, mesmo quando mutilados. Andam de cabeça para baixo. Põem a cabeça no chão, emparafusam-se nas coisas (conhecendo-as por dentro) e no giro, vão dando ideias subterrâneas que servem de guias para a gente se transformar e encarar o mundo ${ }^{40}$.

Ah, a mandinga. Existem muitas histórias sobre as magias do corpo...

Meu filho, vou te levar para conhecer uma senhora, ela reza na folha e depois olha pra folha e diz o que é. Rapaz, essa mulher é tão santa que, às vezes, eu estou com uma dor de cabeça, eu passo, ela tá na porta, eu falo com ela: oi, dona Santa! Pronto, a dor de cabeça passou! ${ }^{41}$

Ah, camaradinhas, o mundo tem seus mistérios! Mandinga é mumunha de "nego véio”, é buraco de cobra, é nó em corda seca, é Besouro Preto que avoa. Mandinga é Exu que carrega azeite em uma peneira e não perde sequer uma gota. É necessário adentrar as gramáticas do encante, praticar os cruzos, permitir o arrepio do corpo e a incorporação de outros saberes.

\footnotetext{
${ }^{37}$ CÉSARIE, Discurso sobre o colonialismo, 2010.

${ }^{38}$ Ver LOPES; SIMAS, Dicionário da História Social do Samba, 2015.

${ }^{39}$ Menção à canção de Wilson Batista "Lenço no pescoço".

${ }^{40}$ CANJIQUinHA, Alegria da Capoeira, p.39.

${ }^{41}$ Fala de Mestre Gerson Quadrado.
} 
Em outra história, o mestre narra:

Rapaz, mestre Gerson Quadrado era tão mandingueiro que, quando ele conheceu mestre Ananias - eu tive o prazer de levar ele na casa dele -, o mestre Ananias perguntou: "Qual é o seu orixá?” Ele respondeu: “Não mecho com isso não." No final, mestre Ananias trocou a língua com ele: "Olorun... não sei lá o quê...”, ele respondeu e o Ananias disse: "Mas você não disse que não era?!” E mestre Gerson: “Eu não posso te dar tudo de vez, Ananias!”

Como cantaria o verso, "valha meu Deus, senhor São Bento, buraco velho tem cobra dentro". As mandingas são os saberes que navegam no invisível e vira e mexe baixam em nós. O cabra mandingueiro é aquele que incorpora o saber que se manifesta e se dilui em questão de segundos. Quem viu, viu! Quem sabe, sabe. Quem está dentro não sai e quem está fora não entra. Ouvi histórias sobre seu Antônio Venâncio, caboclo mandingueiro que curava bicho no rastro, mas que botava quebranto em recém-nascido. Como já disse, é remédio e veneno, mandinga é troço ambivalente. Meu pai me contou: "Eu vi o velho Antônio Venâncio matar uma rês no olhar, como vi também amansar bicho brabo com uma língua que só ele falava! O velho foi picado de cobra venenosa e nada lhe aconteceu." ${ }^{42}$

Ah, a mandinga! Todo saber tem suas mirongas, mumunhas. Minha avó, em suas palavras, me disse:

Meu filho, tem gente que tem poder, uns sabem que têm e faz coisas boas, os que não sabe do poder que têm bota coisa ruim. Eu tinha uma vizinha que não podia entrar aqui em casa que era só ela falar: "dona Neuzinha, tão bonita suas plantas!” Não dava outra: quando eu ia ver, estavam tudo murchas! Você não lembra do que aconteceu com a Joaninha?!

É verdade, tenho que admitir que eu mesmo fui testemunha do enredar dos mistérios das mandingas. Em estadia na casa de minha avó quando eu era criança, caí durante mais de uma semana com febre alta e outros piripaques. Entre hospitais, médicos e muitas receitas, o que eu ouvia é que não era nada demais, porém a febre e a cama me acompanharam por esse tempo.

Até que um dia, no meio da noite, acordei sob uma surra de galho de aroeira acompanhado por uma ladainha que misturava palavras nunca ouvidas a outras identificadas como 'cinco-salomão', 'divino espírito santo' e 'bendito e louvado seja'. À minha frente, uma senhora negra de estatura muito baixa e aparência envelhecida, ao seu lado, minha tia, que me dizia: "Meu filho, não tenha medo que ela irá lhe curar." Coincidência ou não, na manhã seguinte, acordei outro e até me aprontei para um passeio de bicicleta.

${ }^{42}$ Essa história aconteceu nos idos dos anos 1960 no interior do Ceará. 
Muitas são as histórias das mandingas de cura. Sou testemunha do trato curtido nos versos das rezas e ladainhas. Quando criança, fui frequentador assíduo dos encantes das palavras, dos galhos de arruda, fumo de rolo e copos d'água. Às vezes alguns modos chegavam a assustar, como as rezas acompanhadas dos sinais feitos na ponta da faca. Porém, sempre fui acalmado pela máxima: “se bem não fizer, mal também não vai fazer!" Impingem, febre, inflamações, furúnculos, esporros. Da infância para cá, acompanhei alguns modos, tomei reza no Ceará, no Maranhão, tomei lições no Pará e cruzei algumas rotas nos terreiros dos subúrbios do Rio de Janeiro e na Baixada.

Existe uma multiplicidade de mandingas: são técnicas, magias, saberes fronteiriços, encantes que vigoram, protegem e potencializam o corpo. Algumas se inscrevem nas instâncias da cura revelando um amplo repertório terapêutico, formas que tratam e realinham o ser com as condições de sua existência. Outras formas se revelam dinamizando outras instâncias da vida. Assim, existem as mandingas de sorte, que são lançadas no curso dos jogos. A sorte de um se inscreve nas circunstâncias do azar do outro. Não há sorte plena, como também não há azar pleno, a lógica dessa dinâmica se inscreve na ordem do jogo. Por isso, os mais sábios já exaltariam a máxima "devagar também é pressa.”

São muitas as histórias que falam de mandingas, as sapiências do corpo. Uma é o ocorrida entre mestre Martinho da Pemba e um sujeito chamado Dimola, na feira de São Joaquim, em Salvador, onde seu Martinho trabalhou até falecer.

Seu Martinho diz: Vocês conhecem o Dimola? Rapaz, aquele menino é bom! Ele veio aqui pegou uma cana minha (a cana custava 50 centavos, era produzida em uma roça na região de Mapele). Eu disse "me devolve que a cana tem dono!” Ele disse dacolá: “Que isso, coroa, vou levar essa cana!” Eu tornei a dizer: "Você não vai levar não!” Peguei o facão e joguei no pescoço dele! Rapaz, não é que ele 'deitiou' todo?! Quando ele se 'deitiou', eu piniquei e ele rolou. Aí eu disse: "Pode levar a cana!” Ele, de lá, respondeu: "Eu não quero mais não! Não quero mais essa cana não!” Eu tornei a dizer: "Leve, eu gostei! Isso eu conheço muito! Leve a cana, porque foi a primeira vez que eu puxei o zinco para não ver pingar!”

As mandingas se expressam não somente nas curas dos corpos, mas também nos seus sacrifícios. Afinal, cura e sacrifício são termos que, nessas lógicas, só fazem sentido se inscritos e lidos de forma cruzada. Assim, há um repertório infinito de mandingas que se manifestam nos jogos de valentia e nas pelejas de amarração de versos. Saberes corporais atados via versos e movimentos envoltos na atmosfera do encante. Nos campos de batalha, que são também campos de mandinga, o corpo que toca o chão tombado pelo golpe se inscreve como o sacrifício que encanta o rito. 
Assim, como ensinado por seu Martinho da Pemba, haveremos de reconhecer o mérito daqueles que invertem a lógica e usam o poder do seu próprio corpo como potências que o livram do sacrifício. Esses tipos possuidores dessas artimanhas são mitificados como detentores do corpo fechado. Mas o que viria a ser o tal do corpo fechado? Responderei nas palavras diretas, mas encruzadas no enigma versado pelo lendário Madame Satã. Ao ser perguntado se possuía o corpo fechado, o malandro responde: "Ué, meu corpo é fechado porque não está aberto. Agora, sobre isso que você diz, eu digo que é sorte mesmo!”

Mandinga, o conhecimento do invisível, a malícia, o fazer do pouco muito ${ }^{43}$, esperteza, malandragem, o que fez Besouro voar, mágica, ginga particular, manhas, truques, a sapiência do corpo. Mandinga é tudo que a boca come e tudo que o corpo dá! Seu Pastinha, seu Martinho da Pemba, Madame Satã, Mano Elói Antero Dias, dona Santa, seu Martiniano Eliseu do Bonfim, dona Neuzinha, seu Antônio Venâncio, mestre Gerson Quadrado, Padre Cícero, me perdoem, a lista é infinita... As mandingas e incorporações nos têm muito a dizer sobre outros saberes. Talvez não, porque, como bom mandingueiro, há de se lembrar que nem tudo o que se sabe é para ser dito. Porém, a prosa nos invoca importantes problematizações reivindicadas pela Pedagogia das Encruzilhadas.

Dessa forma, retomo as inúmeras respostas que tive ao lançar, em contextos de práticas como a capoeira, o jongo, o candomblé, entre outras muitas manifestações, a pergunta: Como se aprende? As respostas: “Aprendi no pé de fulana!” "Aprendi na barra da saia!” “Aprendi de ouvir!” “Aprendi fazendo!” “Aprendi na marra!” "Aprendi de esperar!" “Aprendi de teimoso!” “Aprendi na barriga de minha mãe!” "Aprendi de ver os mais velhos fazendo!” Todas essas respostas nos dão o tom da complexidade dos saberes e dos horizontes pluriepistêmicos que compõem as diferentes formas de vida e de educação.

Existem muitas outras formas possíveis. A rotina do colonialismo tem sido a de executar milhões de corpos, construir igrejas, catequisar, velar e buscar uma salvação. Porém, aqueles milhões de corpos assassinados, torturados, sequestrados, estuprados, mulheres, crianças e jovens compõem uma tessitura de sabedorias que subsidiam as práticas que disferem golpes na maquinaria colonial. Se para cada centena de mortos pelo colonialismo se constrói uma igreja, na perspectiva das encruzilhadas, cada corpo é um totem que imanta e reverbera potências que significam a vida.

Assim, é nesses termos que, vira e mexe, baixam por aqui praticantes de outros tempos, uns se encantaram em cipós, olhos d’água, pedras de rio, gameleiras e sabiás. Outros se imbricam aos ditos "viventes" e deixam seus recados. Os que me inspiram nessas travessias se fixaram nas esquinas, nos goles de cerveja lançados ao chão, nas nuvens de fumaça, nos requebrados, batidas de mão no couro e no sacrifício da vida regado

43 O “fazer do pouco muito" é uma definição que mestre Cobra Mansa dá sobre a mandinga. Não coincidentemente, na capoeira há um verso popular que diz: "Um pouco com Deus é muito, um muito sem Deus é nada.” 
a dendê. Para o que é lançado a partir de uma via explicativa assentada no complexo cosmológico iorubano, só existe morte pelo esquecimento! Só morre aquilo que não é lembrado. Cuspido feito travessura da boca do Mestre das ruas, em uma conversa, ele manda: "Meu filho, eu estou aqui falando com você, agora me diga eu tô vivo ou tô morto?!"44 (Gargalha...)

Firmo o ponto novamente, a racionalidade moderna ocidental é decapitada e assombrada pela má sorte de ter o corpo (Bara) deslocado da cabeça (Ori). As questões acerca dos saberes (epistemologias) perpassam necessariamente por um reconhecimento e credibilização do corpo, na medida em que todo saber se manifesta quando praticado, ou seja, incorporado. Se as questões acerca do saber estão diretamente vinculadas às dimensões das práticas, incorporações, e dos agentes que as praticam, as incorporam, as questões epistemológicas se inscrevem também como uma problemática étnico-racial.

É defendendo que as problemáticas epistemológicas são também étnico-raciais que me fidelizo a ressaltar as proezas de Bara e Elegbara. A emergência do corpo a partir do signo Exu substancia a crítica e aponta caminhos que despacham a negação dos saberes corporais. As perspectivas advindas dos domínios e potências de Exu são mais um golpe operado pela Pedagogia das Encruzilhadas, que provoca um revés na medida em que traz o corpo para o cerne do debate poético/político/ético. Ao mesmo tempo em que falo das proezas e dos poderes do corpo, falo também da má sorte do mundo Ocidental, que tem suas cabeças deslocadas dos seus corpos. Um mundo de decapitados em que as cabeças caminham em direção contrária a dos corpos.

A perspectiva da pedagogia encarnada por Exu aponta e credibiliza outras travessias no campo do saber. Assim, segundo os conhecimentos versados nos terreiros, Bara é o elemento individual corporificado que, junto ao Ori, individualiza o ser. Bara, o corpo, e Ori, a cabeça, que, integrados, marcam as individualidades e os caminhos que cada um de nós carregamos. Elegbara é o domínio de Exu que o titula como o senhor do poder mágico. A este domínio estão creditados o dinamismo e o pulsar das energias que constituem, conectam e perpassam as existências como um todo. É nos domínios de Elegbara que se assentam os princípios e potências de todo e qualquer movimento e ação criativa. É Elegbara que funde o princípio dinâmico das existências, além de se firmar nos termos de produtor de toda e qualquer possiblidade e imprevisibilidade.

Elegbara é aquele andarilho que vagueia mundos, bate o ogó ${ }^{45}$ no vazio e já está do outro lado, montado em formigas, viaja nos redemoinhos, canta de tardinha e de manhã canta novamente. Elegbara é pinto e galo ao mesmo tempo, é ele que emprenha as moças virgens, desnuda certezas. O brincalhão escreve o ontem no hoje, fuma o cigarro ao avesso sem se queimar, de sua flauta, sopra o espiral do tempo que nos faz acontecer. Elegbara

\footnotetext{
${ }^{44}$ Esse questionamento me foi lançado em um diálogo com a entidade espiritual seu Tranca Rua das Almas.

${ }^{45}$ Ferramenta, instrumento mágico de Exu.
} 
nos encarna, é o moleque travesso que numa hora quer de comer, e um minuto depois já não quer mais. É o dengo e o choro, o gozo e a birra. O garoto querido de Olodumaré, o filho que Orunmilá pediu para mimar. Elegbara vagueia mundos, tropeça e encontra soluções, veste a carapuça que quiser e carrega a cabeça do rei em seu bornal. Nas palavras assentadas na esteira do saber popular dos terreiros, Elegbara "é a força de Exu, o movimento como um todo”. ${ }^{46}$ É um pouco de cada um de nós.

\section{Referências}

CANJIQUINHA. Alegria da Capoeira. Salvador: Editora a Rasteira, 1989.

CARVALHO, José J.; FLÓREZ, Juliana F. Encuentro de Saberes: proyecto para decolonizar el conocimeto universitário eurocênctrico. Nómadas, nº 41, p. 131-147, 2014.

CÉSARIE, Aimé. Discurso sobre o colonialismo. Trad. Anísio Garcez Homem. Florianópolis: Letras Contemporâneas, 2010.

FANON, Frantz. Pele negra, máscaras brancas. Trad. Renato da Silveira. Salvador: EDUFBA, 2008.

FANON, F. Os Condenados da Terra. Rio de Janeiro: Editora Civilização Brasileira S.A, 1968.

GROSFOGUEL, Ramón. A estrutura do conhecimento nas universidades ocidentalizadas: racismo/sexismo epistêmico e os quatro genocídios/epistemicídios do longo século XVI. Revista Sociedade e Estado, v. 31, n 1. Jan-Abr 2016.

LOPES, Nei; SIMAS, Luiz Antonio. Dicionário da História Social do Samba. Rio de Janeiro: Civilização Brasileira, 2015.

MASOLO, Dimas. A. Filosofia e conhecimento indígena uma perspectiva africana. In: SANTOS, Boaventura de Souza; MENEZES, Maria Paula (Orgs.). Epistemologias do Sul. São Paulo: Cortez, 2010.

MBEMBE, Achile. Crítica da Razão Negra. Tradução Marta Lança. Lisboa: Antígona Portugal, 2014.

\footnotetext{
${ }^{46}$ Cabe ressaltar que, devido à aproximação e à imbricação das noções e diante de uma circulação cada vez maior de produções referentes aos ritos negro-africanos, algumas generalizações vêm sendo feitas colocando as noções de Bara e Elegbara como sinônimos. Essas generalizações são comuns, inclusive na literatura acerca do tema. Porém, cabe aqui destacar que, por mais que as duas noções estejam imbricadas, uma interpenetrando a outra, referem-se a títulos distintos, que indicam domínios próprios. Sendo Bara o título referente à condição de dono do corpo, e Elegbara o título referente à condição de o senhor do poder mágico.
} 
82 | O que pode Elegbara? Filosofias do corpo e sabedorias de fresta

PASTINHA, Vicente Ferreira. Improviso de Pastinha. Salvador: Acervo Fred Abreu Capoeira, 2013.

RUFINO, Luiz. Exu e a Pedagogia das Encruzilhadas. Tese de Doutorado- Universidade do Estado do Rio de Janeiro, 2017.

RUFINO, Luiz; SIMAS, Luiz Antonio. Fogo no Mato: a ciência encantada das macumbas. Rio de Janeiro: Mórula, 2018.

TAVARES, Júlio Cesar. Dança de guerra- arquivo e arma: elementos para uma Teoria da Capoeiragem e da Comunicação Corporal Afro-Brasileira. Belo Horizonte: Nandyala, 2012.

TAVARES, J. C. Colonialidade do Poder, Cooperação Internacional e Racismo Cognitivo: Desafios ao Desenvolvimento Internacional Compartilhado. In: ADESKY, Jacques d'; SOUZA, Marco Teixeira de (Orgs.). Afro-Brasil: debates e pensamentos. Rio de Janeiro: Cassará Editora, 2015. 